\title{
Knowledge, Experts and Accountability in School Governing Bodies
}

\author{
Abstract \\ School governing bodies in England have considerable powers and \\ responsibilities with regard to the education of pupils. This paper explores how \\ power relations operate, within governing bodies, through struggles over which \\ types of knowledge are claimed and valued. The paper draws on the analysis of \\ policy and on ethnographic research in the governing bodies of four maintained \\ schools to explore the complex interactions between lay, educational and \\ managerial knowledge. The paper suggests that educational and managerial \\ expertise are privileged over lay knowledge. Hence, the concept of 'lay' \\ knowledge, which is attached to external governors, is easily co-opted by \\ managerial knowledge as it does not have alternative expert knowledge \\ attached to it.
}

\section{Introduction}

School governing bodies (GBs) in England have considerable powers and responsibilities with regard to the education of pupils. In this paper, I explore 
DRAFT of

Young, H. (2015) 'Knowledge, Experts and Accountability in School Governing Bodies'. Educational Management Administration \& Leadership, (ahead-of-print), 1-17. http://dx.doi.org/10.1177/1741143215595415

how power relations operate, within GBs, through struggles over which types of knowledge are claimed and valued. Policy and governors themselves tend to see lay involvement as a 'good thing', often through drawing on conceptions of democracy. However, it is unclear what constitutes lay knowledge, apart from an absence of the expert knowledge held by professional educators.

The relationship of democracy to expert knowledge has provoked debate since at least the time of ancient Athens. Debate about this relationship is often reduced to a simple binary; setting lay knowledge against expert knowledge. However, in the case of GBs, there are at least two significant forms of expert knowledge in play: educational and managerial. The interplay between educational and managerial knowledge and the way in which the positive connotations of lay knowledge can be co-opted by managerial knowledge mean that the relationship between lay and expert is a complex rather than binary relationship. Rose (2005 [1996]) argues that there is a move, in society more broadly, from valuing professional expertise such as educational expertise to valuing managerial expertise. Furthermore, as Foucault suggests, expert knowledge is more than a perspective and, as I will describe, is able to constitute objects in the world. It should be noted that none of the types of knowledge considered here are clearly bounded; they overlap and interrelate so 
Young, H. (2015) 'Knowledge, Experts and Accountability in School Governing Bodies'. Educational Management Administration \& Leadership, (ahead-of-print), 1-17. http://dx.doi.org/10.1177/1741143215595415

categorising them as lay, educational and managerial knowledge operates merely as a heuristic device.

The paper draws on the analysis of policy and on ethnographic research in the GBs of four maintained schools to explore these types of knowledge. It first sets out the approach to research. This is followed by an introduction to GBs in England. Some comments are made about conceptualising forms of knowledge; then the idea of 'lay' as an absence of knowledge is explored. This is followed by sections on the place of educational knowledge; governors' claims to educational knowledge; education as an auditable product; and accountability relationships. The paper concludes that educational and managerial expertise are privileged over lay knowledge and that the concept of 'lay' knowledge associated with external (non-staff) governors is easily co-opted by managerial knowledge as it does not have alternative expert knowledge attached to it.

\section{Approach to research}

This paper has emerged from qualitative research with the GBs of four local authority (LA) maintained schools in one LA in 2011 and 2012. Avon and Severn were primary schools and Mersey and Tyne were secondary schools ${ }^{1}$.

\footnotetext{
${ }_{1}^{1}$ Pseudonyms have been used throughout for the schools and the participants.
} 
Young, H. (2015) 'Knowledge, Experts and Accountability in School Governing Bodies'. Educational Management Administration \& Leadership, (ahead-of-print), 1-17.

The wider study had four research questions related to the under-researched area of democracy and school governing bodies. This paper focuses largely on the second:

1. How do discourses of democracy and citizenship operate in school governing bodies?

2. Are particular perspectives and types of knowledge privileged in policy and in governing bodies? If so, how?

3. What subject positions are available to governors? How are governors produced as subjects?

4. What discourses of 'good' education are drawn on in the conduct of school governing bodies?

The research was broadly ethnographic with a total of 23 meeting observations and 25 interviews. Agendas and minutes were also examined. For each school, at least four observations were conducted. These took place in either two or three full GB meetings and from one to five other micro settings, mostly committee meetings. Semi-structured interviews were conducted with the headteacher, chair of governors and at least four other governors in each 
Young, H. (2015) 'Knowledge, Experts and Accountability in School Governing Bodies'. Educational Management Administration \& Leadership, (ahead-of-print), 1-17. http://dx.doi.org/10.1177/1741143215595415

school. Two of the governors interviewed were governors in two of the study schools. The clerks were also interviewed. The analysis was broadly inductive but guided by the research questions, the literature and my experience based expectations (Hammersley and Atkinson, 2007: 165). I used 'grounded theory methods as flexible, heuristic strategies rather than as formulaic procedures' (Charmaz, 2003: 251).

Furthermore, national policy texts were analysed. The emphasis in this study was on policy that particularly relates to GBs but there was a recognition of the changing context of schools policy and wider public policy. Ball helpfully proposes analysing policy both as text and as discourse (Ball, 2006 [1993]). Governors are not always directly aware of policy texts but are still constituted by policy discourse in complex ways. Policy texts were considered together with observations and interviews which explored aspects of governors' understanding of policy and of their role.

\section{School governing bodies in England}

The plethora of types of school in England means there are many kinds of school GBs. This research took place in the GBs of maintained schools which had one GB per school. Such GBs have considerable powers and duties. At the 
Young, H. (2015) 'Knowledge, Experts and Accountability in School Governing Bodies'. Educational Management Administration \& Leadership, (ahead-of-print), 1-17. http://dx.doi.org/10.1177/1741143215595415

time of the research, their role included: setting the budget, appointing the headteacher and setting the school's broad direction (DCSF, 2010; DfE, 2012; Ofsted, 2011). GBs are made up of 7 to 20 (or even 30) people, including an elected chair, and are supported by a clerk. They meet as a full GB about 6 times a year and have various committees on aspects such as curriculum and finance which meet between these meetings. The basic composition of the GBs of maintained schools at the time of the research was: the headteacher; staff governors elected by staff; parent governors elected by parents; LA governors nominated by the LA; community governors nominated by the GB. This is described as a 'stakeholder' (DfE, 2012) model and is premised on the idea that different stakeholders bring different knowledge to the GB.

There has been an ongoing move to value governors with 'skills' and this was officially introduced into the regulations after the research period (DfE, 2014b: 27). In March 2015, the DfE announced $£ 1$ million to 'help schools across England recruit highly-skilled governors' (DfE, 2015) Governors are not meant to provide, for example, pro bono legal advice (NGA, 2013: 4). However, the statutory guidance on 'The skills governing bodies need' leaves the 'skills' very open and ambiguous (DfE, 2014a: 7). 'Skills' is often used in opposition to 'representation' so the valuing of governors with skills operates to 
Young, H. (2015) 'Knowledge, Experts and Accountability in School Governing Bodies'. Educational Management Administration \& Leadership, (ahead-of-print), 1-17. http://dx.doi.org/10.1177/1741143215595415

simultaneously devalue representative governors with lay knowledge. 'Skills' tend to be associated, in policy discourse and by governors in the study schools, with business and a business rationality. Furthermore, the language of skills reinforces a conception of governing as an apolitical technical process. The ambiguity about what these skills are contributes to these interpretations and effects (Young, 2014). These recent policy moves make an exploration of how particular types of knowledge are valued in GBs particularly salient.

\section{Conceptualising knowledge}

The word 'knowledge' is slippery, complex and contentious. It tends to incorporate information, experience and expertise and is more or less powerful. Furthermore, what is understood as knowledge is increasingly transformed by the dominance of managerial knowledge (Rose, 2005 [1996]) which tends to operate as a meta-knowledge and reduce other types of knowledge to information and/or technical skills. In exploring struggles over knowledge, this paper does not attempt to pin down a fixed conception of 'knowledge' but, rather, exemplifies the slipperiness of the term.

In exploring how governors speak to each other more broadly, conceptions of deliberative democracy (Young, 2002 [2000]; Dryzek, 2002) are very useful. 
DRAFT of

Young, H. (2015) 'Knowledge, Experts and Accountability in School Governing Bodies'. Educational Management Administration \& Leadership, (ahead-of-print), 1-17. http://dx.doi.org/10.1177/1741143215595415

However, they are less useful for considering the role of expertise in deliberation since, as Walter (2008) points out, they tend to conceptualise expertise as just another perspective. Walter (2008) is helpful in considering how expert knowledges such as educational knowledge and managerial knowledge are valued over non-expert knowledge. Expert knowledge is powerful in that it constitutes objects such as 'good education' or 'performance'. Ball's 'performativity' (2006 [2003]) is a striking example and shows how (managerial) knowledge constitutes 'good' education and the role of teachers. As mentioned, the three forms of knowledge, educational, managerial and lay, are being used not as absolute categories but rather as a heuristic device. Therefore, their definitions are porous. Managerial knowledge is primarily being understood in Rose's terms (Rose, 2005 [1996]). I am using it to include knowledge which tends to be seen as technical and transferable, including, for example, legal and human resources knowledge. Following Foucault, Walter points out, "expert knowledges give rise to much of what we "say" and "see" or the objects that we take to exist in the world and how we talk about them' (Walter, 2008: 540). Therefore, 'Expert discourses have a greater capacity to register problems than do non-expert discourses, and this relates to their ability to constitute their objects as elements of the world, as "seeable"' (Walter, 2008: 543). Amongst policy discourse and educational and managerial knowledge, lay 
Young, H. (2015) 'Knowledge, Experts and Accountability in School Governing Bodies'. Educational Management Administration \& Leadership, (ahead-of-print), 1-17. http://dx.doi.org/10.1177/1741143215595415

knowledge can be subjugated, marginalised and rendered unspeakable or untrue. Significantly, governors in the study schools often drew on the educational knowledge which they did have suggesting that this was valued.

\section{‘Lay' as an absence of knowledge}

'Lay' is an ambiguous term. In the context of GBs, it tends to be attached to external governors with an absence of educational knowledge. However, its association with democratic, inclusive processes, local community links and conceptions of 'common sense' give it positive connotations (the positive connotations attached to 'outsider' views have been discussed elsewhere (Young, 2014)). Here, I explore how conceptions of 'lay' are drawn upon in GBs. Much of the GB literature argues for the importance of lay involvement in education. For example Holt and Hinds say, 'It is hazardous to make education the province of professionals only' (1994: 8) and this view was common amongst governors in the study.

The valuing of external governors with lay knowledge is part of a wider approach to public services. 'In the UK, particularly, public service reforms have been accompanied by an approach to organizational governance that allocates a central role to "lay" representation' (Clarke, 2013: 210). As a longstanding 
Young, H. (2015) 'Knowledge, Experts and Accountability in School Governing Bodies'. Educational Management Administration \& Leadership, (ahead-of-print), 1-17. http://dx.doi.org/10.1177/1741143215595415

example of this, governors have long been positioned as not needing educational knowledge:

Governors are ... lay people and their strength has always been seen in these terms (Creese and Earley, 1999: 71)

Most of the governors in the study schools emphasised that they did not need to be experts to be governors, for example:

the most important thing is obviously a love for ... education. And also a sense of commitment. And a head full of common sense. That is all you need. Because at the end of the day anybody [can] understand hopefully, what is right and what is not right (Chaman, community governor and chair, Tyne Secondary)

As suggested by Chaman above, the valuing of external governors is often associated with conceptions of 'common sense' which tend to imply some form of neutral knowledge. As Clarke writes, 'a powerful feature of the figure of "ordinary people" involves a view of them as not political' (2013: 212). However, claims to neutral knowledge obscure their political underpinnings. Linked to this, 
Young, H. (2015) 'Knowledge, Experts and Accountability in School Governing Bodies'. Educational Management Administration \& Leadership, (ahead-of-print), 1-17. http://dx.doi.org/10.1177/1741143215595415

the valuing of external governors with lay knowledge has, to varying degrees, been accompanied by the derision of professional educational knowledge. The ‘discourse of derision' which Ball (2006 [1990]), borrowing from Kenway, first described in the 1970s and 1980s is still prevalent in parts of the media, among right-leaning think tanks and in Department for Education (DfE) justifications for education reforms today. The focus of derision may have shifted from state schools generally towards those which are not academies, but it still 'deploys exaggeration and "ludicrous images, ridicule, and stereotypification... A caricature that has been developed and presented to the public as an accurate depiction of the real" (Kenway, 1990, p 201)' (Ball, 2013: 104).

In relation to the valuing of 'common sense', Deem et al comment on the limitations of the supposed benefits of governors' naivety:

schools are principally about teaching and learning ... there can be immense problems if lay governors have limited knowledge of education systems and/or the school they attempt to govern. These difficulties are not entirely compensated for by the fact that being unfamiliar with something can also help to ensure that taken-for-granted practices in schools are subjected to naïve 
Young, H. (2015) 'Knowledge, Experts and Accountability in School Governing Bodies'. Educational Management Administration \& Leadership, (ahead-of-print), 1-17.

questioning, which can ultimately be beneficial to those working in schools (1995: 160)

Significantly, if governors do not have educational (or, increasingly, managerial) knowledge, it is hard for them to challenge discourses of education which they do not feel that they fully understand. Governors' lack of educational knowledge combined with their legal powers can cause tensions. For example, the NAHT evidence for the 2013 Education Parliamentary Select Committee Inquiry into the role of GBs says:

The government's desire to increase the autonomy of head teachers has led to some conflict with governing bodies. Decisions relating to the length of the school day, the curriculum, etc. still require governing body assent, for example. However, some governing bodies may not have the necessary skills and knowledge to assess fairly the recommendations of the head and therefore either reject outright any change to the status quo or force through inappropriate change (NAHT, 2013: 1) 
Young, H. (2015) 'Knowledge, Experts and Accountability in School Governing Bodies'. Educational Management Administration \& Leadership, (ahead-of-print), 1-17. http://dx.doi.org/10.1177/1741143215595415

I am using 'lay' knowledge to refer to non-expert types of knowledge such as parental experience or local knowledge. I have written elsewhere about the relative marginalisation of parent governors, suggesting that those affected by GB decisions are not necessarily those who are heard in meetings (Young, 2014). This marginalisation is often related to class and ethnicity as well as to the ambiguity of parental 'representation' in the context of governing body meetings. Together these issues make lay voices an even more fragile alternative.

Lay knowledge is strongly valued, partly due to its association with conceptions of democracy. However, it is difficult for 'lay' to be defined as more than an absence. External governors are partly valued for their absence of educational knowledge and partly for bringing fresh perspectives from their 'common sense' knowledge. Hence, lay knowledge is associated with both an absence of expert knowledge and with vague conceptions of 'common sense'. Both of these associations mean that (positive) conceptions of 'lay' are easily co-opted by managerial knowledge which is increasingly seen as 'common sense'. 
Young, H. (2015) 'Knowledge, Experts and Accountability in School Governing Bodies'. Educational Management Administration \& Leadership, (ahead-of-print), 1-17. http://dx.doi.org/10.1177/1741143215595415

\section{The place of educational knowledge}

External governors are not meant to need educational knowledge to be governors. This section explores the power of educational knowledge as a form of expertise and suggests it tends to be valued over lay knowledge.

There are various elements to what might be seen as educational knowledge, for example: teaching; school organisation; social context of teaching; local policies, support and funding; national policies and their implications.

Educational knowledge is configured differently depending on the context and speaker. Some overlap with other fields so it is not always clear what types of knowledge might be counted as educational. For example, having taught in universities might provide a type of educational knowledge.

External governors may start with a double ignorance. Some do not know about education and some do not know about the school. They gather some knowledge about both and attempt to draw on this. There are two key sites of struggle: firstly, claiming valued knowledge and, secondly, claiming which forms of knowledge should be valued. These sites are explored in this section. 
Young, H. (2015) 'Knowledge, Experts and Accountability in School Governing Bodies'. Educational Management Administration \& Leadership, (ahead-of-print), 1-17. http://dx.doi.org/10.1177/1741143215595415

Educational knowledge and the school vision and values

Central within literature about GBs, and echoing conceptions of democracy, is the idea that the GB should set out the 'what' or the ends and the headteacher should decide the 'how' or the means of education (e.g. Walters and Richardson, 1997: 40). Similarly, Simkins cites Winstanley et al (1995) in making a distinction between 'criterion' and 'operational' power:

Criterion power is the ability to define the aims of the system, determine its overall structure and establish the performance criteria against which actors within it will be judged... Operational power, in contrast, is the power to decide how a service is delivered and to allocate resources to its delivery (Simkins, 2012: 4)

The role of GBs in 'setting aims and objectives for the school' (DfE, 2012: 15; DCSF, 2010: 13) set out by the Department for Education (DfE), might suggest that GBs would have 'criterion' power and be very much concerned with discussing the vision and values of their schools. Firstly, this suggests that educational knowledge is not needed to discuss these. Secondly, it implies that 'criterion' power is located in the school and not elsewhere. In this sub-section, I 
Young, H. (2015) 'Knowledge, Experts and Accountability in School Governing Bodies'. Educational Management Administration \& Leadership, (ahead-of-print), 1-17. http://dx.doi.org/10.1177/1741143215595415

question the first suggestion and, in a later sub-section on 'Multiple accountabilities', I question the latter, describing how 'criterion' power is exercised through the rationalities of national government and Ofsted, the national inspectorate.

Governors in the study schools did not engage much in discussions specifically about an overarching vision for their school. There was some variation by phase. In the primary schools, the headteachers said they would have welcomed more input (whether they actually would have is a different matter). In the secondary schools, the headteachers were clear in their interviews that the core vision of their school had been set by them and was not negotiable.

At Avon Primary, there had been a discussion of the school's vision statement before the study period, to which the headteacher and the chair both referred, saying that governors did not know enough to be able to contribute:

we had a vision statement from 2005 which we just, last term, kind of refreshed and updated... [the governors] didn't come up with any ideas or anything different. They were all "oh yeah, that's fine". And when we came with the draft and then they were 
Young, H. (2015) 'Knowledge, Experts and Accountability in School Governing Bodies'. Educational Management Administration \& Leadership, (ahead-of-print), 1-17.

supposed [to comment], you know, that was sort of "any comments you've got, e-mail them before the next meeting" and so on. Nothing really came of it. (Hannah, headteacher, Avon Primary)

we recently did a new school vision statement. And that was a very consultative process the headteacher ran, with ... sort of our key objectives, the learning environment. I don't feel, as a governing body, we had a huge amount of input into it. And that wasn't because we weren't given the opportunity to, it was because I don't think people particularly felt confident in engaging in that sort of wider discussion (Layla, LA governor and chair, Avon Primary)

Governors' lack of engagement might be partly due to the language in which vision statements are expressed which tends to be very broad and hard to disagree with. However, it seems that staff (and pupils) did engage to a much greater extent than external governors did. With regard to the key strategic documents, the School Development Plan (SDP) at Avon Primary and Ofsted Self-Evaluation Form (SEF) at Severn Primary, there were comments on the 
Young, H. (2015) 'Knowledge, Experts and Accountability in School Governing Bodies'. Educational Management Administration \& Leadership, (ahead-of-print), 1-17. http://dx.doi.org/10.1177/1741143215595415

excessive length but governors had little to say about the actual content. At Severn Primary, the sense of the vision being driven by the need to meet the requirements of Ofsted was particularly strong.

The two secondary headteachers had clear visions for their schools which they both said they had made explicit when they were appointed as headteachers. They both perceived themselves as having considerable autonomy and control and did not refer to the considerable constraints of national policy in framing their visions. This is consistent with the discourse of strong and visionary leadership promoted by school leadership organisations such as the National College, an executive agency of the DfE. Their visions were different to each other showing there is some space for variation within the constraints of the national performative system. However, both stem from particular policy discourses. Hayley, the headteacher at Tyne Secondary, said 'we are about results' as the 'students here get one chance [in life]' whereas, at Mersey Secondary, Heidi, the headteacher, placed a greater emphasis on inclusion (in terms of special educational needs and behaviour). They both told me clearly that their visions were not up for debate. 
Young, H. (2015) 'Knowledge, Experts and Accountability in School Governing Bodies'. Educational Management Administration \& Leadership, (ahead-of-print), 1-17. http://dx.doi.org/10.1177/1741143215595415

At Tyne Secondary, the headteacher, Hayley, laughed when I asked how much the governors influence the SDP. She even said the priorities came entirely from her and not from the senior leadership team within the school. The school's vision was written above the budget and was about exam results. There were no indications that it was up for discussion. On the role of the GB in developing the SDP, Tarun, a staff governor, said that, as governors, 'we just give it a stamp of approval really'. In response to my asking about the vision at Tyne Secondary, Lucy, an LA governor and parent said, 'I think Hayley [the headteacher] is very, very forthright about what that is and uncompromising. So I do. I do think it is not really a conversation that we are allowed to have'.

At Mersey Secondary, Heidi, the headteacher, had instigated and maintained an inclusive ethos and Frederick, the chair of governors, said, 'I think we have a common vision as to what we are trying to do at [Mersey]'. He felt that this inclusive ethos would 'soon grow on' new governors. It did seem to be the case that people who became governors at Mersey Secondary largely supported its vision. However, in response to my question about Mersey Secondary's governors raising social justice issues, Heidi asserted strongly that governors would not raise such issues. Christopher, a community governor, felt that big 
Young, H. (2015) 'Knowledge, Experts and Accountability in School Governing Bodies'. Educational Management Administration \& Leadership, (ahead-of-print), 1-17.

values based decisions did not arise in meetings as governors were informed about 'values decisions' rather than being involved in making them:

I mean, we don't very often get big and significant decisions and things on a par with the restructure. And where decisions come through the committee structure, they tend to be of a more technical variety. So signing off of policy. Or agreeing to expenditure. So I'm actually just trying to think whether we ever really have any of the sort of values decisions. Because I think a lot of those are more what we learn about as the governing body. So what we learn about is what the school is doing. Rather than where do we want the school to go (Christopher, Mersey Secondary)

In summary, there were no significant discussions on vision or values in any of the GBs. This was partly due to a lack of knowledge and partly because the headteachers tended to monopolise vision making. The schools did vary. Hannah, the headteacher at Avon Primary, was fairly open about the school's vision but governors did not feel able to engage. Severn Primary's GB was very focused on impressing Ofsted and any vision beyond that did not seem to be 
Young, H. (2015) 'Knowledge, Experts and Accountability in School Governing Bodies'. Educational Management Administration \& Leadership, (ahead-of-print), 1-17. http://dx.doi.org/10.1177/1741143215595415

discussed. At Tyne Secondary, Hayley, the headteacher, made it clear that the vision was not up for discussion. At Mersey Secondary, it might have been possible to have had a discussion but Heidi, the headteacher, was clear that she would not stay in a school which did not have a strong focus on inclusive education. The limited discussions which governors engaged in on the schools' visions and values challenge the idea that governors have 'criterion' power to set the strategic direction in schools. Lack of educational knowledge was a key factor here.

\section{Headteachers take a lead}

The way in which headteachers took a lead showed the strength of their educational knowledge in combination with their other forms of power. Headteachers know more about education and about their schools and the governing role is part of their full-time jobs. It is not, therefore, surprising that they should want to set the agenda and be well placed to do so despite the fact that the GB is meant to govern the school. My finding that headteachers take a lead resonates with my experience as a governor and with other studies (Radnor et al., 1997: 213; Farrell, 2005: 108; Arnott, 2000: 71; Munn, 2000: 103). However, it is important to point out that, as in Dean et al's study, 'it was not necessary for heads to be manipulative in order for governor involvement to 
Young, H. (2015) 'Knowledge, Experts and Accountability in School Governing Bodies'. Educational Management Administration \& Leadership, (ahead-of-print), 1-17.

be limited. Governors were quite capable of putting limits on themselves' (2007: 42). The headteachers tended to take a lead based on setting the agenda and developing plans to present to governors for approval. The headteachers all told me how they took a lead, in a manner consistent with the national discourse of visionary leadership, for example:

actually you, as the headteacher, are telling them what has to be in place. You are leading them all the time (Hazel, headteacher, Severn Primary)

Governors' lack of educational and contextual knowledge is an important factor in headteachers taking a strong lead in GB meetings. However, headteachers' strong lead in relation to governors should not be taken to mean that headteachers are actually as autonomous as the national leadership discourse might suggest. As Ozga says of 'leadership', it 'is now associated with energetic followership of government policies' (2000: 356). Much of the validation and demarcation of 'proper' knowledge is done elsewhere in leadership manuals and courses, in the media and in national policy texts and output requirements. 
DRAFT of

Young, H. (2015) 'Knowledge, Experts and Accountability in School Governing Bodies'. Educational Management Administration \& Leadership, (ahead-of-print), 1-17. http://dx.doi.org/10.1177/1741143215595415

How governors get informed or educated

The headteachers spent a lot of time trying to 'inform' their governors. The teacher governors also felt they had a role in informing the external governors and reinforcing the headteacher's views. In addition to the information and persuasion provided by headteachers and staff governors during meetings, governors learnt about their role, education in general and their school through staff presentations, visits, being link governors (for example, 'maths governor') and training. All this inducted governors into the particular approach of their school. Training provided by the LA (or, for example, Modern Governor) tends to focus on clarity about their role and to induct governors into an effectiveness discourse in which education is an auditable product (see below). As a result, governors do not gain 'really useful knowledge' (Johnson, 1979) which they might use to challenge prevailing discourses of 'good' education and articulate others. Alternative approaches to induction and training might involve deeper educational processes which enable governors to reflect on the aims of education and on what democratic deliberation and involvement could mean. This could enhance their learning from the existing opportunities of presentations and visits. Another possibility is the development of 'counterpublics' (Fraser, 1997: 81; Vincent and Martin, 2005: 126) where 
Young, H. (2015) 'Knowledge, Experts and Accountability in School Governing Bodies'. Educational Management Administration \& Leadership, (ahead-of-print), 1-17.

parents, for example, could develop their views together before bringing them to the GB.

Governors' claims to educational knowledge

As discussed, external governors have limited educational knowledge.

However, they do have some from a range of sources, for example: being a parent; their own education; work in other schools; being a governor elsewhere; being a trustee of an educational trust; governor training; the media; and Ofsted reports. They tended to refer to the sources of their knowledge frequently to give authority and credibility to their interventions. The way in which governors tended to draw on any educational knowledge they had suggests that they perceived such knowledge to be particularly valuable and relevant, over and above lay knowledge.

Shifting conceptions of professionalism

Educational expertise is now less valued than it was. In the 'state of welfare', experts had "the capacity to generate "enclosures", relatively bounded locales or fields of judgement within which their authority is concentrated, intensified and rendered difficult to countermand' (Rose, 2005 [1996]: 50). Educational professionalism as described by Vincent and Braun has been powerful: 
Young, H. (2015) 'Knowledge, Experts and Accountability in School Governing Bodies'. Educational Management Administration \& Leadership, (ahead-of-print), 1-17. http://dx.doi.org/10.1177/1741143215595415

the label of "professionalism" and the source of its appeal rest on societal assumptions of the autonomy, discretion, status and selfregulation open to "professional" occupational groups (2011: 777)

Educational professionalism is increasingly undermined and displaced largely by another field and conception of professionalism, that of managerial professionalism. This is generic and has no specific relevance to education. There is a movement away from educational professionals to the "grey sciences" (Rose, 2005 [1996]: 54). 'Michael Power has suggested that audit, in a range of different forms, has come to replace the trust that formulae of government once accorded to professional credentials (Power 1992, 1994)' (Rose, 2005 [1996]: 55).

The national derision of educational professionals opens up space for both neoconservative 'common sense' and for the valuing of managerial knowledge. This displaces reflexive and deliberative practice based on considering principles with narrow skills and competencies. In the micro-contexts of the GBs studied, there was not so much neoconservative 'common sense'. Managerial professionalism was strongly valued alongside educational professionalism 
Young, H. (2015) 'Knowledge, Experts and Accountability in School Governing Bodies'. Educational Management Administration \& Leadership, (ahead-of-print), 1-17. http://dx.doi.org/10.1177/1741143215595415

(which has, itself, already been transformed by managerialism) limiting the space for non-expert knowledge.

\section{Education as an auditable product}

Education is being transformed into an auditable product as the emphasis is increasingly placed on aspects which can be measured. This has significant implications for the knowledge which is valued within GBs. This transformation into an auditable product makes education 'intelligible', through data analysis, to those with managerial knowledge. 'The powers once accorded to positive knowledges of human conduct are to be transferred to the calculative regimes of accounting and financial management' (Rose, 2005 [1996]: 54). It is a powerful discourse as it constitutes what education actually is.

Governors are increasingly expected to understand education as a product and to focus on 'performance'. James points out that 'Performance was not specifically referred to' in the 1988 Education Reform Act (2012: 6) whereas now, 'the performance of schools couched in terms of pupil attainment has become a central concern in both governance and governing (James et al, 2011)' (James, 2012: 6). This shift is partly illustrated by the second of Ofsted's 2011 list of 'Key characteristics of effective governing bodies' which says, 
Young, H. (2015) 'Knowledge, Experts and Accountability in School Governing Bodies'. Educational Management Administration \& Leadership, (ahead-of-print), 1-17. http://dx.doi.org/10.1177/1741143215595415

'Governors are well informed and knowledgeable because they are given highquality, accurate information that is concise and focused on pupil achievement. This information is made accessible by being presented in a wide variety of formats, including charts and graphs.' (2011: 5). This quote indicates the slipperiness of 'knowledge' and the way that managerial knowledge can operate as a meta-knowledge reducing other types of knowledge to information. The quote suggests that governors become knowledgeable by receiving information. This presumes their knowledge is managerial knowledge which enables them to understand the, largely statistical, information.

In some GB meetings, it was almost possible to forget the meetings were about schools. As mentioned earlier, there were limited discussions about educational issues. Discussions could have been about any product. This sense was reinforced by where the secondary school GB meetings were held. Meetings at Tyne Secondary were held in a conference room with no indication that it was part of a school and Clark commented,

I thought the library was a better environment because there are books around there. [It] Make[s] you think actually what we are 
Young, H. (2015) 'Knowledge, Experts and Accountability in School Governing Bodies'. Educational Management Administration \& Leadership, (ahead-of-print), 1-17. http://dx.doi.org/10.1177/1741143215595415

about: books and teaching kids and if there weren't children here, we wouldn't be here (Clark, clerk, Tyne Secondary)

Leonard talked about the importance of staff presentations for reminding everybody they were discussing a school:

we try to make sure that everybody knows that they are at the governing body meeting of a school by having a presentation every time ...I don't see enough of the school in session (Leonard, LA governor, Tyne Secondary)

Understanding education as a product leads to focusing on managerial perspectives, largely from business:

One consequence of this is new kinds of "professional dominance", that is, the logics of accountants, lawyers and managers, are made more powerful over and against the judgements of teachers, doctors and social workers (Ball, 2008: 50) 
Young, H. (2015) 'Knowledge, Experts and Accountability in School Governing Bodies'. Educational Management Administration \& Leadership, (ahead-of-print), 1-17. http://dx.doi.org/10.1177/1741143215595415

Managerial knowledge is understood in policy around GBs and by the governors in the study to stem largely from those in business. Simkins lists five beliefs which are central to managerialism. One of these is 'that the techniques for achieving better management are knowable: indeed they are known and generally applicable - they can often be found in best practice in the private sector' (Simkins, 1997: 31). One example of this is the surprise of Connor, a community governor at Tyne Secondary with a business background, that data did not reveal a straight-forward correlation between gender, ethnicity and attainment:

Deidre [deputy headteacher] clarifies about the boy/girl attainment gap. There is a focus on supporting year 11 girls.

Connor - is there an ethnic dimension? Are they Somali?

Deidre - no, they are a mixture

Connor - "so interesting, you can never really nail it can you?"

(my notes, Tyne Secondary Curriculum Committee, July 12)

Some aspects of managerial discourse were more visible and were raised as problematic. However, the discourse of education as a product never really seemed to be challenged. Critiques of business governors with managerial 
Young, H. (2015) 'Knowledge, Experts and Accountability in School Governing Bodies'. Educational Management Administration \& Leadership, (ahead-of-print), 1-17. http://dx.doi.org/10.1177/1741143215595415

knowledge tended to relate to other issues and were heard in interviews much more than in meetings. Hayley, the headteacher at Tyne Secondary, found that business governors could be impatient about change as they do not, she argued, understand how schools work and that 'change takes time'. As staff governors in secondary schools, Tarun and Sally referred to the lack of empathy and of understanding of the public sector ethos and realities and complexities of schools which they felt that some of the business governors displayed.

Over and beyond the issues raised above, there are theoretical and practical limitations to what governors, even with managerial knowledge, can understand from decontextualized data:

Hot knowledge grows cold when far away from its point of origin.

The knowledge which takes pride of place in official thinking is very cold indeed ... Performance indicators are prime examples of decontextualized and cold knowledge ... They have the advantage of producing easily comparable data whereas everything we know suggests that the components of school performance include 
Young, H. (2015) 'Knowledge, Experts and Accountability in School Governing Bodies'. Educational Management Administration \& Leadership, (ahead-of-print), 1-17.

subtle and complex processes and contextual factors (Kogan, 2002, p. 338 cited by Glatter, 2012: 569)

Hayley seemed to be referring to this 'cold' knowledge when she pointed out that governors' lack of educational knowledge means that there are limits to what they can understand from the data:

[Governors] can look at the headline figures but won't necessarily understand what underpins that, that you can get variations in the ability levels in a year group (Hayley, headteacher, Tyne Secondary)

The move to understanding education as a product has many significant implications. In the context of this paper, a key implication is the devaluing of types of knowledge other than managerial knowledge and the implications of this for democratic engagement. James suggests that:

Arguably, the legitimacy of schools in England - and therefore their governing bodies - is seen increasingly in terms of performance, narrowly construed, more than other wider 
considerations. This shift has implications for the democratic accountability purposes of school governing and is reflected in the responsibilities of school governing bodies and the governance system as a whole. (2012: 15)

There is a (limited) struggle between educational and managerial knowledge in relation to education as a product. Furthermore, when education is seen as a product, a managerial discourse pre-empts alternative understandings of lay engagement such as a democratic discourse. There is limited space remaining for the voices of those who can claim neither educational nor managerial expertise.

\section{Accountability relationships}

The role of GBs in 'holding schools to account' came up frequently in policy documents and in interviews. 'Criterion' power (Simkins, 2012: 4) is about setting aims. In contrast to this, accountability seems to be largely about checking that the school is meeting specific ends rather than addressing questions about what those ends should be. Governors are meant to do both. 
Young, H. (2015) 'Knowledge, Experts and Accountability in School Governing Bodies'. Educational Management Administration \& Leadership, (ahead-of-print), 1-17. http://dx.doi.org/10.1177/1741143215595415

The types of knowledge required for accountability (checking prescribed ends are met) are different to those required for setting the strategic direction of the school. This section considers how accountability operates as a slippery concept allowing managerial discourses, partially cloaked as democratic discourses, to dominate education discourses.

\section{Accountability as a slippery concept}

Accountability was unanimously seen as a good thing by all those who raised it in interviews and observations. However, its meaning shifted and these shifts appeared to be hidden and unrecognised. Some sense of democratic accountability may be at the root of the positive feeling the term engendered. However, common usages seemed to be highly reductive and simply about analysing data and about preventing wrongdoing, with implications for the types of knowledge which are valued. The first theme is explored under 'Data-based accountability' and the second under 'Compliance checking' below.

In their evocatively entitled article, 'Into confusion: LEAs, accountability and democracy', Ball et al (1997) distinguish two types of market accountability: 'accountability through service provision' and 'accountability through effective financial management' (148) and two types of political accountability, 
Young, H. (2015) 'Knowledge, Experts and Accountability in School Governing Bodies'. Educational Management Administration \& Leadership, (ahead-of-print), 1-17.

'accountability through elected representatives' and 'outward accountability' (148). They describe how slippages between forms of accountability have led to consumer-based understandings displacing citizen-based understandings. The same confusion seems to exist with governors and the meaning of accountability often slips between these ideal types. Another aspect of the slipperiness of 'accountability' is the way it constitutes managerial accountability as responsible conduct:

As Bruce Charlton has argued, accountability is a "slippery rhetorical term" with at least two largely distinct meanings: a technical-managerial meaning and a looser, more general meaning. In general discourse, accountability has to do with responsibility and carries connotations of "being answerable to". The technical meaning on the other hand, refers narrowly to the duty to present auditable accounts. Charlton observes that originally "accountability" referred only to financial documentation. The current managerial use of accountability is, however, a direct extension of this financial usage: an accountable organization is one that has the duty to present auditable accounts of all of its activities. The link between the two meanings of accountability is 
Young, H. (2015) 'Knowledge, Experts and Accountability in School Governing Bodies'. Educational Management Administration \& Leadership, (ahead-of-print), 1-17.

weak... Yet the rhetoric of accountability operates precisely on the basis of a "quick switch" between the two meanings, making it difficult to see an argument against accountability as anything other than a plea for irresponsible action (emphasis in original, Biesta, 2004: 234-235)

Slippages in accountability discourse are a key way in which a lay discourse is overlaid with a managerial rather than an educational discourse. Political accountability is displaced by market accountability and challenges to this market accountability can be constituted as calls for irresponsible action. Perhaps, educational professionalism could not be so easily displaced by a managerial discourse without the positive connotations suggested by lay involvement.

In the study schools, understandings of accountability seemed to be data-based accountability and compliance checking. Both of these are examples of 'operational power' where the aims are set elsewhere. 
DRAFT of

Young, H. (2015) 'Knowledge, Experts and Accountability in School Governing Bodies'. Educational Management Administration \& Leadership, (ahead-of-print), 1-17. http://dx.doi.org/10.1177/1741143215595415

\section{Data-based accountability}

As Glatter (2012: 559) says, accountability has been increasingly associated with performance. Hence, by the time of the Coalition government, ‘accountability' could be equated solely with 'systematic and external pupil-level assessments' (DfE, 2010: 51). After the research period, the 'Governors' Handbook' was published further strengthening the emphasis on governors' access to 'objective data' as central to 'Holding the headteacher to account' (DfE, 2014c: 8-13).

When education is recoded as a product, as described in the previous section, it follows that accountability becomes primarily associated with managerial knowledge. The state sets outcomes which schools are expected to achieve. The performance based accountability structures such as league tables and Ofsted could be seen as encompassing goals. However, these goals differ from more philosophical aims about 'What schools are for and why' (White, 2007). This state based outcome setting appears to mean that GBs are left to monitor these outcomes rather than set or even discuss aims. This is partly a question of the level at which democratic decisions are made and the conceptions of democracy drawn on. State based outcome setting could theoretically stem from nationwide democratic debate on national entitlements. However, the 
Young, H. (2015) 'Knowledge, Experts and Accountability in School Governing Bodies'. Educational Management Administration \& Leadership, (ahead-of-print), 1-17. http://dx.doi.org/10.1177/1741143215595415

limited nature of national democratic debate challenges this perspective.

Furthermore, under neoliberalism, there is limited space for discussions of aims at a national level as,

under the culture of accountability, the state only wants to be held accountable in terms of the "quality" of its delivery of public services, and not in political, let alone democratic terms (Biesta, 2010: 70)

The relationship between parents, local communities and the state in setting aims and outcomes is complex. Where the state sets rigid outcomes, there is little space for parents and local communities to set their own aims. It is questionable, then in what sense and to what extent governors have a 'strategic' role if their primary function is that of using managerial knowledge to push schools to achieve targets set by the government.

\section{Compliance checking}

Another commonly deployed meaning of accountability was about checking the headteacher was not doing anything wrong. The two secondary headteachers told me: 
Young, H. (2015) 'Knowledge, Experts and Accountability in School Governing Bodies'. Educational Management Administration \& Leadership, (ahead-of-print), 1-17. http://dx.doi.org/10.1177/1741143215595415

I think the head has to be accountable to somebody. Otherwise you can run amok and do what the hell you like (Heidi, Mersey Secondary)

they have to have that level of accountability... I think that you do need that. Because, not least the fact that we could very quickly become megalomaniacs (Hayley, Tyne Secondary)

This form of compliance checking was difficult for governors, since the headteacher tends to lead, as mentioned earlier, and there was an emphasis on developing a trusting relationship between the headteacher and the rest of the GB. Compliance checking can feel like an explicit display of mistrust of the headteacher which is socially awkward and especially difficult when discussion is constrained.

Both contextual and educational knowledge is needed for much compliance checking. There seems to be a paradox in that the GB is only able to hold the headteacher to account if the headteacher allows them to do so by being open. The 'Governors' Handbook' refers to the 2002 Education Act (S.30) and states, 
Young, H. (2015) 'Knowledge, Experts and Accountability in School Governing Bodies'. Educational Management Administration \& Leadership, (ahead-of-print), 1-17. http://dx.doi.org/10.1177/1741143215595415

'It is the headteachers' job (and in maintained schools it is their legal duty ${ }^{\cdots}$ ) to give governing bodies all the information they need to do their job well' (DfE, 2014c: 9). As the headteacher of Mersey Secondary, Heidi explained:

I have to make sure, you know, that I keep all the sort of the statutory regulations and to make sure that they ... do what they need to do and they have the right information because they wouldn't necessarily know what they're meant to do, so [I] tell them (Heidi, Mersey Secondary)

\section{Multiple accountabilities}

The performative national system means governors' space for action is very constrained. Centralised assessment targets and league tables mean that 'any new autonomy at the periphery is in relation to means rather than policy ends, which are set more tightly by the centre as part of a new regime of outcomes accountability' (Rizvi and Lingard, 2006: 255). Governors are part of complex 'networks of accountability' (Rose, 2005 [1996]: 56) which pre-empt the 'criterion' power that might be invested in GBs. They serve and are served by the others, such as league tables, Ofsted and audit. Ofsted visits and reports were frequently referred to as important in all of the GBs. These multiple 
DRAFT of

Young, H. (2015) 'Knowledge, Experts and Accountability in School Governing Bodies'. Educational Management Administration \& Leadership, (ahead-of-print), 1-17. http://dx.doi.org/10.1177/1741143215595415

accountability mechanisms are supported by the GB emphasising data-based accountability and compliance checking rather than broader democratic accountability.

\section{Reflections}

This paper has explored knowledge, experts and accountability using three forms of knowledge, educational, lay and managerial, as a heuristic device. Based on empirical data from GBs, it has explored aspects of the relationship between democracy and expert knowledge. Debate about this relationship is often reduced to a simple binary: setting expert knowledge against lay knowledge. However, in the case of GBs, there are at least two significant forms of expert knowledge in play: educational and managerial. The interplay between educational and managerial knowledge and the way in which the positive connotations of lay knowledge can be co-opted by managerial knowledge mean the relationship between lay and expert is a complex rather than binary relationship.

There is an ongoing trend in education towards the disruption of educational knowledge by managerial knowledge. Nonetheless, external governors make claims in terms of both managerial and educational knowledge whenever they 
Young, H. (2015) 'Knowledge, Experts and Accountability in School Governing Bodies'. Educational Management Administration \& Leadership, (ahead-of-print), 1-17. http://dx.doi.org/10.1177/1741143215595415

can which suggests that both forms of expertise are valued. Conceptions of 'lay' and of 'accountability' both have positive connotations which stem largely from vague but positive associations with democracy. However, in the context of a larger struggle between managerial and educational knowledge, lay knowledge, with its lack of associated expertise, is easily marginalised and displaced by managerial knowledge.

Two dominant understandings of accountability in play within GBs have emerged from the data; they are data-based accountability and compliance checking. Both require managerial and/or educational knowledge. Furthermore, both understandings of accountability are about checking that the school meets aims set elsewhere. They are not about setting strategic aims for the school as might be expected from democratic accountability.

The power of expert knowledge to constitute that of which it speaks is an important reason why lay knowledge is marginalised and provides only a fragile alternative. I understand Ball to be referring to the potential of non-expert knowledge, what I have called 'lay knowledge' when he describes the 'empowerment of community discourse' (Ball, 1994: 89) of 20 years ago. He said then that it was, 
Young, H. (2015) 'Knowledge, Experts and Accountability in School Governing Bodies'. Educational Management Administration \& Leadership, (ahead-of-print), 1-17.

represented primarily in rhetoric rather than in widespread practice (Vincent 1993). Its historical status in the post-war UK politics of education is one of irritant and unrealised hope (Ball, 1994: 92)

It seems that the complexities of the relationships between different forms of knowledge mean that lay knowledge is now being further displaced by managerial knowledge within both policy and practice.

The issues discussed in this paper reflect deeper trends in wider society towards increasing managerialism and the marginalisation of non-managerial voices. Challenging these trends is difficult. However, it is hoped that research such as this, which explores how these trends operate, can provide some basis for stakeholders to challenge them through their 'everyday practices' (Ball and Olmedo, 2013: 90) within their own particular contexts. Potential spaces for thinking differently about how knowledge, experts and accountability operate in governing bodies might exist in governor selection, induction, development and self-assessment as well as in the conduct of all aspects of governing body meetings. 
DRAFT of

Young, H. (2015) 'Knowledge, Experts and Accountability in School Governing Bodies'.

Educational Management Administration \& Leadership, (ahead-of-print), 1-17.

http://dx.doi.org/10.1177/1741143215595415

\section{Acknowlegements}

The original research for the article formed part of my PhD which was funded by

an ESRC Studentship. Additional support was provided through a BELMAS

Bursary in 2014. Professor Carol Vincent and Professor Stephen Ball have

provided extremely helpful support and advice. I am also very grateful to two

anonymous reviewers for their comments on an earlier version of this paper.

\section{References}

Arnott M. (2000) Restructuring the governance of schools: The impact of 'managerialism' on schools in Scotland and England. In: Arnott M and Raab CD (eds) The governance of schooling: Comparative studies of devolved management. London: Routledge, 52-76.

Ball SJ. (1994) Education reform: A critical and post-structural approach, Buckingham: Open University Press.

Ball SJ. (2006 [1990]) The New Right and discourses of derision. In: Ball SJ

(ed) Education policy and social class: The selected works of Stephen J. Ball. London: Routledge, 26-42.

Ball SJ. (2006 [1993]) What is Policy? Texts, trajectories and toolboxes. In: Ball SJ (ed) Education policy and social class: The selected works of Stephen J. Ball. London: Routledge, 43-53.

Ball SJ. (2006 [2003]) The teacher's soul and the terrors of performativity. In: Ball SJ (ed) Education policy and social class: The selected works of Stephen J. Ball. London: Routledge, 143-156.

Ball SJ. (2008) The education debate, Bristol: Policy Press.

Ball SJ. (2013) The education debate, Bristol: Policy Press.

Ball SJ and Olmedo A. (2013) Care of the self, resistance and subjectivity under neoliberal governmentalities. Critical Studies in Education 54: 85-96.

Ball SJ, Vincent C and Radnor H. (1997) Into confusion: LEAs, accountability and democracy. Journal of Education Policy 12: 147-163.

Biesta G. (2004) Education, accountability, and the ethical demand: Can the democratic potential of accountability be regained? Educational theory 54: 233-250.

Biesta G. (2010) Good education in an age of measurement: Ethics, politics, democracy, London: Paradigm. 
Charmaz K. (2003) Grounded theory: Objectivist and constructivist methods. In: Denzin NK and Lincoln YS (eds) Strategies of qualitative inquiry. 2 ed. London: Sage, 249-291.

Clarke J. (2013) In Search of Ordinary People: The Problematic Politics of Popular Participation. Communication, Culture \& Critique 6: 208-226.

Creese M and Earley P. (1999) Improving schools and governing bodies: Making a difference, London; New York: Routledge.

DCSF. (2010) A Guide to the Law for School Governors, London: Department for Children, Schools and Families.

Dean C, Dyson A, Gallannaugh F, et al. (2007) Schools, governors and disadvantage, York: Joseph Rowntree Foundation.

Deem R, Brehony K and Heath S. (1995) Active Citizenship and the Governing of Schools, Milton Keynes: Open University Press.

DfE. (2010) The Importance of Teaching: The Schools White Paper 2010, Norwich: TSO.

DfE. (2012) The Governors' Guide to the Law, London: HMSO.

DfE. (2014a) The constitution of governing bodies of maintained schools:

Statutory guidance for governing bodies of maintained schools and local authorities in England, May 2014. London: DfE.

DfE. (2014b) Governors' Handbook: For governors in maintained schools, academies and free schools. HMSO.

DfE. (2014c) Governors' Handbook: For governors in maintained schools, academies and free schools. HMSO.

DfE. (2015) £1 million to help schools recruit high-calibre governors. Available at: https://www.gov.uk/government/news/1-million-to-help-schoolsrecruit-high-calibre-governors.

Dryzek J. (2002) Deliberative democracy and beyond: Liberals, critics, contestations, USA: Oxford University Press.

Farrell C. (2005) Governance in the UK public sector: The involvement of the governing board. Public Administration 83: 89-110.

Fraser N. (1997) Justice interruptus: Critical reflections on the "postsocialist" condition, New York: Routledge.

Glatter R. (2012) Persistent Preoccupations The Rise and Rise of School Autonomy and Accountability In England. Educational Management Administration \& Leadership 40: 559-575.

Hammersley M and Atkinson P. (2007) Ethnography: Principles in practice, London: Routledge.

Holt A and Hinds T. (1994) The new school governor: Realizing the authority in the head and governing body, London: Kogan Page. 
James C. (2012) Trends in the Governance and Governing of Schools in England. Local Government Studies: 1-17.

Johnson R. (1979) 'Really useful knowledge': Radical educaiton and workingclass culture, 1790-1850. In: Clarke J (ed) Working class culture: Studies in history and theory Birmingham: Hutchinson and CCCS, 75-102.

Munn P. (2000) School boards and governing bodies: A vehicle for parental participation in decision-making about schools? In: Arnott M and Raab CD (eds) The governance of schooling: Comparative studies of devolved management. London: Routledge, 93-115.

NAHT. (2013) Written evidence submitted by National Association of Head Teachers: Evidence submitted to the Education Select Committee Inquiry into 'The role of School Governing Bodies'. Available at: http://data.parliament.uk/writtenevidence/WrittenEvidence.svc/EvidenceP $\mathrm{df} / 189$.

NGA. (2013) Written evidence submitted by the National Governors Association to the Education Select Committee Inquiry on 'The role of School Governing Bodies'. Available at: http://data.parliament.uk/writtenevidence/WrittenEvidence.svc/EvidenceP $\mathrm{df} / 174)$.

Ofsted. (2011) School governance: Learning from the best, London: Ofsted.

Ozga J. (2000) Leadership in Education: The problem, not the solution? Discourse 21: 355-361.

Radnor H, Ball S and Vincent C. (1997) Whither democratic accountability in education? An investigation into headteachers' perspectives on accountability in the 1990s with reference to their relationships with their LEAs and governors. Research Papers in Education 12: 205-222.

Rizvi F and Lingard B. (2006) Globalization and the Changing Nature of the OECD's Educational Work. In: Lauder H, Brown P, Dillabough J-A, et al. (eds) Education, globalization, and social change. Oxford: Oxford UP, 247-260.

Rose N. (2005 [1996]) Governing "advanced" liberal democracies. In: Barry A, Osborne T and Rose N (eds) Foucault and political reason. Abingdon, Oxon: Routledge, 37-64.

Simkins T. (1997) Autonomy and accountability. In: Fidler B, Russell S and Simkins T (eds) Choices for Self-Managing Schools. London: BEMAS with Paul Chapman Publishing.

Simkins T. (2012) Governance of Education in the United Kingdom: Convergence or Divergence? Local Government Studies: 1-17. 
Young, H. (2015) 'Knowledge, Experts and Accountability in School Governing Bodies'.

Educational Management Administration \& Leadership, (ahead-of-print), 1-17.

http://dx.doi.org/10.1177/1741143215595415

Vincent C and Braun A. (2011) I think a lot of it is common sense....': Early years students, professionalism and the development of a 'vocational habitus'. Journal of Education Policy 26: 771-785.

Vincent $C$ and Martin J. (2005) Parents as citizens: Making the case. In: Crozier G and Reay D (eds) Activating Participation: Parents and teachers working towards partnership. Stoke on Trent: Trentham.

Walter R. (2008) Foucault and radical deliberative democracy. Australian Journal of Political Science 43: 531-546.

Walters J and Richardson C. (1997) Governing schools through policy: A blueprint for creative school governance, London: Lemos \& Crane.

White J. (2007) What schools are for and why. Impact 2007: vi-51.

Young H. (2014) Ambiguous Citizenship: Democratic practices and school governing bodies Humanities and Social Science. Institute of Education, London.

Young IM. (2002 [2000]) Inclusion and Democracy, London: Oxford University Press. 